\title{
The Public Sermon: Paul's Cross and the culture of persuasion in England, 1534-1570
}

\author{
W. J. TORRANCE KIRBY
}

McGill University

La tribune en plein air située dans l'enceinte de la cathédrale St-Paul de Londres, et connue sous le nom de la « croix de Paul », compte parmi les plus importants lieux publics de l'Angleterre de la Renaissance. Dans une société où le sermon était le vecteur principal d'éducation des adultes, de direction morale et de contrôle politique, la croix de Paul constituait la tribune ultime, voire la tribune publique de l'Angleterre elle-même. Elle était de longue tradition le lieu des proclamations officielles civiles et religieuses. Les intervenants dûment approuvés y exposaient les politiques gouvernementales et $y$ dénonçaient les hérésies et les rébellions. Pourtant, à l'opposé de l'abbaye royale de Westminster, St-Paul appartenait davantage aux sujets qu'à la monarchie. En dépit du règlement officiel, la croix de Paul offrait un forum populaire favorisant l'exposition de divers points de vue dans le domaine turbulent des idées religieuses et politiques. Dès le XIII ${ }^{e}$ siècle, l'enceinte cathédrale avait été le lieu préféré des protestations populaires, un endroit où le peuple pouvait donner libre cours à ses doléances, et où les enjeux vitaux de la nation prenaient corps. On a dit que « la Réforme anglaise s'était faite à la croix de Paul ». Dans ce cas, quel était le rôle du sermon public dans la formation du public religieux et des identités de l'Angleterre de l'époque? Qui étaient les principaux agents et acteurs? Comment étaient constitués les auditoires? Quelles sont les ruptures et les continuités dans l'utilisation de cette tribune publique au cours des différentes étapes de la Réforme anglaise, du règne d'Henri viıI à celui d'Élizabeth Ière?

$\mathrm{O}$ $\mathrm{n}$ the $11^{\text {th }}$ of July 1533 , Clement VII excommunicated Henry viII in response to Archbishop Thomas Cranmer's annulment of the King's marriage to Katherine of Aragon and his ensuing coronation of Anne Boleyn. ${ }^{1}$ Clement's action and the official response by the King and Privy Council constitute a striking moment of high-stakes political drama laden with significance for the future definition and formation of religious identities in early-modern England. Papal exercise of spiritual jurisdiction in such circumstances presupposed the concept of the so-called "plenitude of power" (plenitudo potestatis), whereby spiritual and temporal authority were bound together in hierarchical relation. By means of a ritualized, sacramental 
act Clement (representing the old "horizon" of meaning) succeeded in cutting the thread of hierarchy which linked Henry—and through him, his entire realm - to the sacramentally inter-connected framework that was Christendom. Correspondingly, by virtue of his adamant defiance of papal jurisdiction, Henry (representing an emerging new "horizon") confirmed this momentous break of the bond of union between the temporal and spiritual orders. The excommunication of Henry may be viewed symbolically as a decisive step in the transition to modernity; indeed it is arguably an archetypical instance of the dissolution of the received sense of the cosmos as a coherent, unified, and continuous order of spiritual/eternal and external/ temporal realms and powers - a process Max Weber defined as the "disenchantment of the world."2 Through their joint action, perhaps inadvertently in both cases, the two rulers successfully shattered the long-assumed moral framework of hierarchical order-the ontological horizon of Christendom, so to speak-within which Henry and his subjects had, until then, lived out their religious lives. In effect, through a single, simple sacramental act and through a determined assertion of political will to ignore that act, Clement and Henry together set in motion a sequence of events which would result in the eventual annulment of "the sacramental" itself as the governing hermeneutical framework of religious self-understanding. In their dispute over the locus of supreme ecclesiastical jurisdiction, the Reformation - and with it modernity - was both figuratively and effectively launched in England.

There is ongoing debate among Reformation historians whether the enactment of the royal supremacy was of merely external political significance, an adjustment of religious organization at the level of constitutional order- "kings and queens messing about" as Christopher Haigh once put it—or, alternatively, was intrinsically theological and broadly metaphysical in scope, and therefore represented a fundamental revision of religious identity. ${ }^{3}$ Was Henry's claim to the title of ecclesiastical headship merely a "naked act of power with no visible moral basis"? 4 In the case of Clement Armstrong, an avant-garde Protestant in the circle of Thomas Cromwell, Ethan Shagan has shown that evangelicals could be strongly supportive of the new political theology. ${ }^{5}$ At the same time, the phenomenon commonly described as "Henrician Catholicism" refers to a sacramental religiosity where much remained the same in spite of the transfer of supreme ecclesiastical power from the Bishop of Rome to the King. ${ }^{6}$ Although roundly rejected by such as Sir Thomas More and John Fisher, this deeply conservative brand of reform was the contemporary view promoted by survivors like Stephen Gardiner and Edmund Bonner. ${ }^{7}$ Although the monasteries were dissolved, the Mass remained, as did the splendour of ritual; clerical celibacy was reaffirmed and private masses, auricular confession, and much 
else besides conveyed a sense of continuity with late-medieval religious identity, especially after the enactment in 1539 of the Statute of the Six Articles ${ }^{8}$ and the fall of Thomas Cromwell in 1540. ${ }^{9}$ Yet at root the question would appear to have much to do with "first principles" of religious identity, that is to say, with certain fundamental hermeneutical assumptions and what Charles Taylor has identified as "moral ontology." By their respective actions, Henry and Clement initiated the conditions for a radical transformation of English religious identity which in fact proved irreversible. Most significant from the standpoint of the present inquiry, this dispute over jurisdiction was the occasion for the explosive growth of a virtually unprecedented "culture of persuasion"10 diversely manifest in both print (as, e.g., in sermons, pamphlets and tracts, printed proclamations, parliamentary statutes) as well as in various other publicly "staged" productions (the preaching of sermons, performance of plays, public trials and executions, and formal disputations) all of which effectively combined in the middle years of the sixteenth century to fill an increasingly conspicuous void left by the progressive dismantling of the traditional, late-medieval "sacramental culture."11 The flourishing of a new culture of persuasion contributed in turn to the early emergence in England of what later came to be called the "public sphere."

Charles Taylor remarks at the outset of Sources of the Self that "moral sources of emerging modern identity are far richer than the impoverished language of modernity's most zealous defenders." ${ }^{12}$ His point is very plain: a critical element of this impoverishment of language is a neglect of the ontological, theological, and metaphysical categories which, in Taylor's view, constitute the groundwork or foundation for these sources. Therefore, following Taylor's lead in our attempt to recover some of these rich sources of early-modernity in the context of Tudor struggles over religious identities, we propose first to trace some steps whereby disputation concerning certain key hermeneutical and theological assumptions gave rise to a significant alteration in the sense of these identities, and secondly to explore how transformed religious identities contributed in turn to generating a rudimentary, but nonetheless recognizable early-modern instance of a public sphere of discourse. ${ }^{13}$ It must be recalled that in this Tudor period, religious discourse was the primary, most universal discourse "through which [the public] interpreted its own existence." ${ }^{14}$ Our aim, then, is to attempt to hold together within a single view questions related to the reconstruction of early-modern "religious identity," the related conspicuous expansion of a "culture of persuasion," and the resulting emergence from this of a recognizably "public" arena of discourse. In order to further this intent, the concrete historical focus of our exploration of these intersecting themes will be the open-air 
pulpit in the precincts of St Paul's Cathedral known as "Paul's Cross" for reasons which I hope will become clear as our inquiry proceeds. For the present, may it suffice to observe that one of Chancellor Thomas Cromwell's first acts following Henry's excommunication was to give the order that none should be permitted to preach at Paul's Cross without declaring the authority of the Bishop of Rome (as he was henceforth to be named) was no greater in England than that of any other foreign bishop..$^{15}$

\section{Paul's Cross: the "public pulpit"}

Without any doubt the open-air pulpit in the precincts of St. Paul's Cathedral known as "Paul's Cross" can be reckoned among the most influential of all public venues in early-modern England. In a world where sermons generally counted among the conventional means of adult education, as vital instruments of popular moral and social guidance, not to mention political control, Paul's Cross stands out as London's pulpit of pulpits; indeed it lays claim to being the "public pulpit" of the entire realm, and was arguably more of a stage than a preaching station. It was an arena of vital consequence where "the conscience of church and nation found public utterance," particularly in moments of crisis. ${ }^{16}$ Very large crowds, sometimes numbering in thousands, gathered here to listen to the weekly two-hour sermons. On one occasion after delivering a sermon at Paul's Cross not long after the accession of Elizabeth, John Jewel wrote in a letter to his mentor Peter Martyr Vermigli in Zurich that as many as 6,000 people stayed afterwards to sing metrical psalms. ${ }^{17}$ Going back to the thirteenth century St. Paul's churchyard had been a bustling public space, a privileged venue for the announcement of royal proclamations and papal bulls to citizens of the capital. At Paul's Cross spokesmen authorized by both Crown and Church expounded government policy and denounced heresy and rebellion. Yet, unlike the royal Abbey of Westminster, St Paul's was always perceived as belonging more to subjects than to princes, and this peculiar status was to acquire increased significance over time. From the earliest records it is clear that the cathedral churchyard was one of the favoured settings for popular protest, a place where public grievances could be aired. For centuries this was the meeting place of London's folk-moot; royal guarantee of the liberties of the City was proclaimed here in the reign of Henry III; Paul's Cross was also a rallying point for adherents of Simon de Montfort's rebellion. ${ }^{18}$ In the sixteenth century this place was the acknowledged epicentre of a series of revolutionary events where matters of religious identity were concerned. 
In his magisterial history of the Paul's Cross sermons, Millar MacLure observed that "The Paul's Cross pulpit was nothing less than the popular voice of the Church of England during the most turbulent and creative period of her history," ${ }^{19}$ although what is meant by a "popular voice" here is ambivalent given the degree of government control. At times, especially during sessions of Parliament, the auditory must have seemed a microcosm of the whole realm, "all England in a little room," and indeed an early-seventeenth-century painting shows us each member of the audience in his place, properly accoutred, "groundlings and notables, pit and galleries, and in the midst, the pulpit as stage." ${ }^{\circ}$ Paul's Cross frequently served as the public face of government when Thomas Cromwell and Thomas Cranmer orchestrated propaganda for the Henrician reformation in the 1530 s in the aftermath of Clement VII's issuing his bull of excommunication. Preaching campaigns at Paul's Cross bolstered Matthew Parker's Advertisements of religious uniformity in the mid-156os as well as the attempts by John Whitgift and Richard Bancroft to stem the rising tide of Disciplinarian Puritanism during the Admonition controversy and later. It was popularly claimed that "all the English Reformation was accomplished from the Cross," very much under the watchful eye of senior bishops and the tight control of the Privy Council. ${ }^{21}$ These conditions, of course, by no means meet the requirements of a "public sphere" by a strictly Habermasian measure. ${ }^{22}$ Yet, between 1534 and the end of the sixteenth century, this pulpit remained continuously at the centre of events which transformed England's religious identities, and through this transformation contributed substantially to the emergence of a public arena of discourse animated above all by a "culture of persuasion."

Of prime significance is the fact that the transition from a late-medieval to an early-modern religious identity was achieved to a very large extent through persuasion - arguments, textual interpretation, exhortation, reasoned opinion, and moral advice. At the end of the reign of Elizabeth, religious identity could no longer be assumed as simply "given" within the accepted order of the world. Structures which had previously connected a hierarchically ordered cosmos to a parallel, interconnected religious understanding in late-medieval "sacramental culture" had given way, even among adherents of Rome, to a "culture of persuasion." One has only to peruse MacLure's Register of Sermons preached at Paul's Cross, 1534-1642 to obtain an impression of this epic transformation. ${ }^{23}$ At one time or another, all of the significant players among the ecclesiastical and university establishments put in an appearance on stage - John Fisher, Cuthbert Tunstall, and Stephen Gardiner, Thomas Cranmer, Hugh Latimer, and Nicholas Ridley, John Jewel, John Whitgift, Richard Hooker, and Richard Bancroft are just a few of the prominent preachers 
who "made their exits and their entrances" in the tortuous course of the English Reformations. Yet, the full significance of their appearances is not to be interpreted solely with regard to their official standing in traditional institutions-Church, Parliament, or University. Their contribution to a nascent public sphere is to be interpreted rather through the arena of their discourse - their relation to the audiences, and their reliance upon the devices of rhetoric and argument to shape religious identity. The dynamic of stage and audience at Paul's Cross promoted an emerging sense of religious identity shaped by the instruments of exegesis, argumentation, and exhortation. It is through such a dynamic that the sense of an emerging "public" open to persuasion begins to take hold and to redefine religious identity.

Paul's Cross is arguably the single most important vehicle of public persuasion to be employed by government from the initiation of the Henrician Reformation in the early 1530 s down to the final years of the reign of Elizabeth. On this claim rests a further assertion that the formation of England's succession of religious identities in this period comes to depend to a high degree on the words uttered here. The emergence at Paul's Cross of an increasingly sophisticated "culture of persuasion" moving concurrently with public policy was intrinsic not only to the formation of a new Protestant religious identity, but also to the articulation of a Counter-Reformation Catholic identity. In part this was owing to the intimate proximity of pulpit and press. The names of dozens of printers and booksellers are identified on colophons in the period 1530 to 1600 as "dwelling in Paules churchyarde," and by rough estimate they are in the majority. Virtually all booksellers not in Paul's churchyard are located nearby within the sound of Bow bells. It is certainly no mere happenstance that a large part of the book trade in sixteenth-century London was conducted within hailing distance of Paul's Cross. ${ }^{24}$ The "culture of persuasion" which issued from the pulpit continued on its course in print. Yet it would be advisable not to exaggerate the role of print culture with respect to the pulpit. Andrew Pettegree has cautioned that any account of how Protestantism could become a mass movement in an age before mass literacy must be careful to "relocate the role of the book, as part of a broader range of modes of persuasion," and especially with respect to public preaching. "Scripturally-based preaching is restored to its central place as the 'bedrock' around which the churches harnessed other communication media." ${ }^{25}$ Nowhere is this more accurately applied than in the case of Paul's Cross. Yet curiously the sermon remains a much neglected genre in the study of this period. ${ }^{26}$

To begin our brief survey of the role played by Paul's Cross in the formation of Tudor religious identities, taking the formal break with Rome as our point of departure, on 15 January 1534 the traditional prayer for the pope was omitted at 
the Paul's Cross sermon following a memorandum issued by Thomas Cromwell to John Stokesley, Bishop of London, on the previous day. ${ }^{27}$ As part of Cromwell's orchestrated campaign of propaganda in the months following in support of legislation moving through Parliament to confirm Henry's headship of the Church, "every Sunday preached at Paul's Cross a bishop who declared the Pope not to be head of the church." ${ }^{28}$ Many sermons of the mid-1530s dwell on the theme of "how every king hath the highe power under God, and oughte to be the supreme head over all spirituall prelates." ${ }^{29}$ Yet somehow in August 1536, a royal chaplain managed to slip underneath Cromwell's radar to preach a sermon questioning the King's supremacy. In the opinion of William Marshall, acting as the Lord Chancellor's observer, the Bishop of London had permitted "a rabblement of seditious preachers" at Paul's Cross..$^{30}$ Edward Lee, Archbishop of York, on the other hand, "did right well touching the supremacy, as touching the condemnation of the rebels [of the Pilgrimage of Grace]." ${ }^{11}$ On 12 May 1538 Friar John Forest refused to do public penance for denying the Royal Supremacy before the assembled company surrounding the pulpit, perhaps signalling some alteration in public mood. ${ }^{32} 1540$ witnessed sermons both for and against Lutheran doctrine delivered respectively by Thomas Cranmer and Stephen Gardiner. ${ }^{33}$ This is significant from the standpoint of Christopher Haigh's observations concerning England's multiple Reformations. ${ }^{34} 1540$ marks the transition from the evangelical phase of the 1530 s to the more conservative final years of Henry's reign. The key point is not so much about a process of "confessionalizing" and its undeniably murky development so far as England is concerned, as it is about the broad commitment by proponents of widely diverse confessional positions to the practices of a common "culture of persuasion."

8 July 1543 saw the recantations at Paul's Cross of avant-garde evangelicals Thomas Becon, Robert Wisdom, and Robert Singleton. On 6 July 1544 the playwright John Heywood was required to recant his adherence to the supremacy of the Bishop of Rome. ${ }^{35}$ The acknowledgment of the royal supremacy and the affirmation of Lutheran doctrine continued to be at odds for the remainder of Henry's reign. It is interesting to note in passing that the well-established medieval practice of public penance and recantations at Paul's Cross continued throughout the Reformation period and well into the seventeenth century until the destruction of the pulpit in 1643. MacLure's Register notes frequent and regular occurrence of penitents "bearing faggots" and recanting "damnable errors and heresies" throughout the reigns of Henry viII and all three of his progeny. ${ }^{36}$ In this penitential drama conducted at Paul's Cross there is an interesting juxtaposition of the concerns of the individual soul with those of higher, political significance, an intersection of what 
Calvin referred to as the inward forum of the conscience (forum conscientice) and the outward forum of the public arena (forum externum et politicum). ${ }^{37}$ It would seem that the more sharply the "self" is delineated, the more clearly a recognizably "public" forum comes into play. Both self and public sphere emerge with sharper definition as the sacramental hierarchy with its intricate, graduated disposition of reality recedes from its place as the dominant hermeneutic. On 26 September 1546 numerous heretical books and pamphlets were burned at the Cross during the sermon, including Tyndale's English New Testament and Coverdale's Bible. ${ }^{8}{ }^{2}$ On 16 January 1547, less than two weeks before the death of Henry viII, John Feckenham, almoner to Edmund Bonner, deplored the advance of Lutheran heresy among the younger generation. ${ }^{39}$

Feckenham's apprehension was to prove prescient. Shortly after the accession of Edward vi, William Barlow denounced the veneration of images and smashed two icons while standing in the pulpit at Paul's Cross, himself an instance of the new power of persuasion since he had earlier written a tract attacking the abuses of the Lutheran heretics..$^{\circ}$ On 18 January 1548 Hugh Latimer preached his celebrated "Sermon on the Ploughers," certainly one of the most famous sermons preached in the course of the English Reformation. ${ }^{41}$ Latimer calls upon all London to a common act of penitence, although "London cannot abide to be rebuked, such is the nature of man" and "in this behalf I must speak here to my country, England, as Paul did in his first epistle to the Corinthians." 42 In a sermon preached in June following, Stephen Gardiner boldly reasserted the conservative Henrician stance; he upheld the king's supremacy, and at the same time affirmed the traditional Catholic teaching concerning the Mass, transubstantiation, and the doctrine of "Real Presence." 43 Shortly thereafter, Richard Cox, Dean of Christ Church and Vice-Chancellor of Oxford University, entered the pulpit to offer his riposte. Wriothesley notes that "All thoys preachers that prechyd at Powlles crosse at that time spake moche agyne the bysshope of Wynchester."44

Perusal of extant Paul's Cross Sermons shows a heavily disproportionate emphasis throughout the period 1534 to 1570 on Gardiner's two themes above all others: namely, the royal claim to ecclesiastical jurisdiction and the status of the sacrament. With respect to the Supremacy, there are discernible phases of rhetoric employed. Sermons of the "first Reformation" (1533-1539) place strong emphasis on justifying the principle of the King's supremacy, while those of the "second Reformation" (1547-1553) stress the obedience of subjects to an institution now clearly recognized. When a Protestant settlement became increasingly secure in the third phase of Reformation under Elizabeth, sermons on the supremacy strike 
a more celebratory note, especially in the Accession Day sermons on 17 November. These were occasions of solemn annual rehearsal of communal memory with the affirmation of royal governance of the Church as their focus. ${ }^{45}$ Moving thus through distinct rhetorical phases from exposition of the principle (under Henry), through exhortation to obedience (under Edward), and finally to commemoration (under Elizabeth), there is a gradual evolution of religious identity. The influence of the external forum of public persuasion is brought to bear in turn upon the faculties of the inner forum of the conscience-understanding, will, and memory-with each receiving the appropriate emphasis as circumstances required.

To continue, for the moment, with our rehearsal of highlights of the action at Paul's Cross, 1549 witnessed several Anabaptists "bearing a faggot" in token of their recantation of heretical errors. ${ }^{46}$ In July Thomas Cranmer's chaplain, John Joseph, "rehearsed" - that is to say, summarized - a "sermon conernynge the tyme of rebellion" composed by the Florentine reformer and then Regius Professor of Divinity at Oxford, Peter Martyr Vermigli, although actually preached by Cranmer at St. Paul's the previous week, just a few days after the imposition of martial law. ${ }^{47}$ In the aftermath of the rebellion of 1549, Thomas Lever, Master of St. John's, Cambridge, preached in the Shrouds - a chapel beneath the Cathedral choir where Paul's Cross sermons were delivered during inclement weather-against disobedience and social injustice..$^{8}$ The rebellion must be interpreted. Ordered to preach in support of religious reform on 1 September 1549, Edmund Bonner chose to assert Christ's real presence in the sacrament in defiance of Cranmer and the Edwardian establishment, and soon found himself imprisoned for his pains. Such episodes underline the degree to which the fully fledged public sphere described by Habermas has yet to appear, and yet the very fact that a religious conservative like Bonner is given the opportunity of the pulpit is itself a remarkable occurrence. 49

On 9 July 1553 the shoe was clearly on the other foot. Nicholas Ridley preached in the same pulpit in support of the succession of Lady Jane Grey, on the same day that Privy Counsellors and the guard swore their obedience to her, and was subsequently burned at the stake in Oxford for his indiscretion..$^{\circ}$ At Mary's accession, Thomas Watson, Bishop of Lincoln, guarded by 200 men-at-arms "with bills and halberds," counselled the congregation at Paul's Cross to "keep the ould faithe, and edifye the ould Temple againe." ${ }^{1}$ Stephen Gardiner, now Lord Chancellor, stepped up to the pulpit on 30 September 1553 to condemn the preachers of Edward's reign and to praise Mary's consort, King Phillip II of Spain. Henry Machyn reports that on this occasion there was "as grett a audyensse as ever I saw in my lyff." 52 Phillip himself attended at Paul's Cross later that same year to hear Gardiner proclaim 
England's readmission into Catholic Christendom..$^{53}$ Exploitation of all the tools of public persuasion had by now become definitive of both evangelical reformers and Catholic conservatives alike.

Just two days after the accession of Elizabeth on 17 November 1558, her chaplain William Bill preached at Paul's Cross by royal order and, according to Machyn, "mad[e] a godly sermon." 54 That the new regime was off to a very shaky start was made plain the Sunday following when John Christopherson, Marian Bishop of Chichester, vehemently denounced Bill and encouraged his audience to "believe not this new doctrine; it is not the gospel, but a new invention of new men and of heretics." 55 After this initial pulpit skirmish there followed several months' silence while the Council sought to consolidate power. No more sermons were heard at Paul's Cross until the scholarly Matthew Parker was appointed to preach the following February, at the very time he was desperately seeking to avoid elevation to the See of Canterbury. Edmund Grindal proclaimed restoration of the Book of Common Prayer from Paul's Cross in May 1559. On the 26 November following, before as "grett audyense as (has ever) bene at Powlles Crosse," John Jewel, bishop-elect of Salisbury, preached his famed "Challenge Sermon," a sharply focused and sustained attack on the doctrine, rites, and ceremonies of the Roman church, and quite possibly the most broadly influential of all sermons delivered at Paul's Cross throughout the Tudor era. ${ }^{56}$ Jewel's sermon marks a significant watershed in the history of Paul's Cross in light of the subsequent cultivation of religious identities in England (use of the plural is salient in this connection), and, perhaps most important of all, in the maturation of the Tudor "culture of persuasion," and hence in the gradual emergence of a recognizable early-modern instance of the public sphere.

In content Jewel's Challenge Sermon is not markedly different from what had been common fare at Paul's Cross since the days of Thomas Cromwell's propaganda campaign of the 1530 s. There are, however, certain subtle differences of rhetoric and, even more importantly, of the sermon's public reception which set apart this particular pulpit event as one of remarkable significance for the formation not only of English religious identity at the outset of the reign of Elizabeth, but also of early-modern identity in a larger, more general sense. Jewel's rhetorical gambit was to seek reversal of the burden of proof; he challenged the adherents of Rome to demonstrate the truth of their position on various aspects of sacramental doctrine and practice: private masses, communion under one kind, prayers in a strange tongue, transubstantiation, and the veneration of images as well as the question of the jurisdiction of the Bishop of Rome. Jewel urged the autonomy of regional churches and the supremacy of Christian Princes. (Here we find once again the 
two constantly recurring themes of Paul's Cross sermons-jurisdiction and the sacraments.) He repeated the challenge in a Court sermon on 17 March and once again at Paul's Cross on 31 March 1560.57 Gary Jenkins has pointed out that most of the finer distinctions of eucharistic doctrine were undoubtedly "too arcane for the vast majority of the faithful in England to have contemplated, let alone considered at length." ${ }^{8}$ Nonetheless, this particular Paul's Cross sermon caused an unprecedented commotion that continued on the boil for several years. Over the course of the next decade, Paul's Cross reverberated repeatedly with repercussions of Jewel's Challenge and the printing houses in Paul's church-yard were kept busy as never before. Henry Cole, Marian Dean of St. Paul's, was the first to step up to the plate in an exchange of letters later published in a pamphlet together with the now famous sermon. ${ }^{59}$ In the meantime, Jewel had honed his argument further and published it anonymously in Latin under the title Apologia ecclesice anglicance. ${ }^{60}$ It was soon translated by the formidable Anne Cooke, Lady Bacon, second wife of Sir Nicholas; "the accuracy and stylistic distinction of her work received gratifying and immediate recognition when Archbishop Matthew Parker arranged publication of his manuscript copy, making her words the voice of the established church." ${ }^{61}$ On 30 April 1564, Alexander Nowell, Henry Cole's replacement as Dean of St. Paul's, preached at Paul's Cross in response to Thomas Harding's cogent Ansvvere to Maister Iuelles chalenge. ${ }^{62}$ Attacks on Jewel in print were swiftly multiplying and Dean Nowell was in the pulpit once again in November to reply to yet another, viz. Thomas Dorman's Defence of Catholyke Beleef dedicated to his patron Harding. ${ }^{63}$ As a consequence Nowell and Dorman became involved in an exchange of five books, with Dorman's last salvo returning to direct attack on Jewel's original sermon. ${ }^{64}$ Harding answered Jewel again with his Confutation of the Apology, and Jewel preached again at Paul's Cross in reply to Harding on 27 May $1565 .{ }^{65}$ At this point Thomas Stapleton leapt into the fray with the publication of his Fortress of the Faith. ${ }^{66}$ Pulpit and press had become thoroughly intertwined in the furious pace of what became known as the "Great Controversy." ${ }^{7}$ After being deprived of his prebend at the Cathedral of Chichester for refusing to repudiate papal primacy, Stapleton eventually joined William Allen in founding the English College at Douai. From there Stapleton launched yet another salvo attacking Jewel's reply to Harding, while in the meantime Jewel had begun to pull together his massive Defence of the Apology. ${ }^{68}$

As the fur continued to fly and as a measure, moreover, of how public the confrontation had become, even foreigners were drawn into the struggle to define England's religious identity. In an epistle to Queen Elizabeth translated by Richard Shacklock, another Louvainist, Portuguese bishop Hieronymous Osorius cut to 
the chase when he warned that Protestants "go about to pul insondre the fences and inclosures of all lawe and religion." By breaking long established theological assumptions and religious custom, "all feare is put to flight, and licentiouse living dothe raigne withoute comptrollment." By virtue of Jewel's assertion of Justification by faith alone and by his repudiation of the authority of the Papacy, "there shall ryse manyfolde yea infinite religions one contrary to the other ... for every man wyll invent a churche, according to his own fantasye." ${ }^{\text {" } 9}$ As though it were a tennis match, Osorius was answered in turn by the distinguished Latinist Walter Haddon, translator of the Liber Precum Publicarum (1560) and key contributor to the Reformatio legum ecclesiasticarum (1571)..$^{70}$ Such were the escalating stakes in what had become one of the epic confrontations of the English Reformation. And of course the high profile of Paul's Cross was not only decisive in precipitating the exchange, it continued to function prominently in the unfolding struggle to define religious identity. All told, the contributions of Jewel and his allies combined with the counter-offensive led by the English recusant exiles centred at Douai and the University of Louvain produced more than 40 treatises and pamphlets within seven years of the original "Challenge Sermon" at Paul's Cross..$^{71}$ Throughout this protracted torrent of words preached and published, tacitly acknowledged by all participants in the "Great Controversy" were certain common rules of engagement. While the polemical tone from all quarters was almost invariably harsh and abrasive, there was, nonetheless, a concerted attempt by all to employ rhetoric in order to persuade, to resolve the conscience through closely reasoned biblical exegesis, cogent argumentation, and especially through judicious interpretation of ecclesiastical tradition. A particularly fierce battle was waged over conflicting claims to patristic authority which had the long-term effect of launching modern Patristic scholarship. In pulpit and press "who owns the Fathers?" became a watchword among the disputants, and in the midst of the struggle the birth-pangs of modern critical scholarship can be discerned. Seventy-four editions of the writings of the Early Church Fathers were published between 1536 and 1600 , half of which comprise tellingly the works of Augustine..$^{72}$ As the debate unfolded, Augustine proved a pivotal authority in working out the underlying "moral-ontological" differences between the old "sacramental" horizon and the new horizon of "persuasion."

\section{Religious identity, the culture of persuasion, and the public sphere}

In less than 30 years between the launching of Thomas Cromwell's propaganda campaign in 1534 and the publication of Jewel's Apologia in 1562, the economy of 
religious discourse in England had undergone a truly remarkable transformation. On a substantive level, traditional common assumptions upheld for centuries concerning the nature of religious identity had been called into question. At the same time, on an instrumental level, the rhetorical means employed in the unfolding of this radical questioning of religious identity in both evangelical challenge and traditionalist response - whether through pulpit or press - were ineluctably bound up with the substantive content of the changes. Put another way, how the principles of religious identity were communicated became inseparable from what was actually being communicated. It is important to recognize that at a fundamental level in these events "the medium is the message," to borrow MacLuhan's well-worn expression. ${ }^{73}$ The conflict between Jewel and his interlocutors appears to have had the effect of galvanizing the recurrent issues aired in the pulpit at Paul's Cross over the previous 25 years. The main thrust of the Challenge Sermon was to highlight opposition between what we have identified (following Charles Taylor's formulation) as two competing "moral ontologies." 74 In his history of the emergence of modern identity Taylor points out that the moral ontology behind any given set of views is more likely than not to remain largely implicit.75 The interpretation proposed here is that the competing moral ontologies underpinning their respective religious identities are brought fully into sharper relief in the course of the controversy precipitated by Jewel's challenge at Paul's Cross. It is precisely the clarity of Jewel's formulation of the kernel of this question of identity that sparks the great public debate of the 1560s. Issues previously largely implicit had been made explicit.

While a considerable variety of questions occupied the preachers at Paul's Cross over the preceding decades, we have already observed a recurring emphasis on two questions in particular: first, the nature of sacramental "presence" and the sacramental itself in terms of the doctrine of the Mass, and secondly, the relation between religious and political power in light of the royal assumption of supreme ecclesiastical jurisdiction. The success of Jewel's Challenge sermon is to weave these two primary thrusts of controversy into a single, focused debate. Jewel proposes an explicit link between religious practices and sacramental phenomena, on the one hand, with the question of the more fundamental axioms of an essential, underlying framework-Taylor's moral ontology. The acerbity and sustained intensity of the ensuing exchange between Jewel and his numerous interlocutors of the Louvain school, as well as others, are evidence of a significant escalation in the stakes of this public disputation. The Great Controversy of the 1560 os brings the question of religious identities to focus on fundamental axioms, and both parties to the dispute plainly recognize that these axioms are definitive of the universal moral-ontological 
framework within which the more specific and particular concerns of religious identity are ultimately determined. Charles Taylor states concerning identity in general that it is defined by

... the commitments and identifications which provide the frame or horizon within which I can try to determine from case to case what is good, or valuable, or what ought to be done, or what I endorse or oppose. In other words, it is the horizon within which I am capable of taking a stand ... To know who you are is to be oriented in moral space, a space in which questions arise about what is good or bad, what is worth doing and what not, what has meaning and importance for you and what is trivial and secondary. ${ }^{76}$

The doctrine of the Mass, its main corollaries and supports-transubstantiation, veneration of images, private masses, communion under one kind, prayers in a strange tongue-become, on Jewel's account, the selected criteria for addressing, weighing, and finally judging a complete ontological framework. The invocation of a forensic image here is crucial. This is a trial. A charge is levelled, the prosecution makes its case, the defence is heard, and after a summing up, judgment is delivered. While the conduct of the trial no doubt presupposes the presence of the powerful agents of Crown, Parliament, Church, University, and City - in the pageant of a sermon at Paul's Cross all of them represented in one way or another the judges in a very vital sense are the assembled audience. The most important trial is to be conducted in an open court of public judgment. All of the devices of persuasion are aimed ultimately at securing conscientious embrace of the argument. The judgment of the learned is without doubt of the highest consequence, but ultimate success will depend also on popular embrace of that judgment.

Over against the Mass, Jewel sets justification by faith and the competing ontological framework it represents. Modern pluralist assumptions are apt to produce genuine discomfort at the confidence assumed in such formulations. As Taylor points out, we now tend to view any and all such "frameworks" as intrinsically optional and that this is just a necessary consequence of the advancing "disenchantment" that is modernity.77 Yet Taylor is surely correct in his observation that "in earlier ages ... when the major definition of our existential predicament was one in which we feared above all condemnation, where an unchallengeable framework made imperious demands on us, it is understandable that people saw their frameworks as enjoying the same ontological solidity as the very structure of the universe." 78 Thus, for example, in defence of the Roman ecclesiastical hierarchy culminating in the papacy, Nicholas Sanders invokes the Christian Neoplatonic moral ontology of 
the cosmic "lex divinitatis," the law of the so-called "great chain." Sanders appeals to just such an assumption of ontological solidarity when he claims that

Where many Countries, tong[ue]s, Rulers and teachers are in one body, and as it were many Capitaines in one great armie of men, (as there are in the church of Christ) there, if order be not exactly kept, great and horrible confusion must needes follow. The conservation of order, is to have a known Iudge, whose finall sentence in all controversies all men may both heare and obey. ${ }^{79}$

Without finality of judgment all order dissipates. The papacy as the "known judge" who brings down a "finall sentence" is thus the most crucial link to the ontological order as sacramentally interpreted. Yet, even for Sanders the authority of this final sentence is no longer simply given or presupposed within the universal hierarchical order of reality. Argument, demonstration, persuasion must be invoked in order to convince the public that such a judge is necessary, that the Pope himself is in actuality that author of the "finall sentence." In effect Sanders appeals to the instruments of the "culture of persuasion" in order to justify and defend the "sacramental culture." From a competing framework or moral-ontological assumption, Jewel will argue that unity and order subsist within the horizon implied by the sovereignty of the godly Prince. The Royal Supremacy is the epiphenomenon of a different ontological assumption, one which challenges the moral assumptions of the "great-chain" ontology as interpreted by Sanders, Harding, and the rest of the Louvainists. Thus a distinct religious identity with its manifold phenomenal consequences derives from a different moral axiom and from the revised "horizon" defined by that alternative axiom.

It is the role of the pulpit in this "trial" - and increasingly also of the press and print culture, although derivatively, following the pulpit's lead-to employ every possible means of persuasion to bring an ever more discerning public to conscientious affirmation of the framework, the moral ontology, and the fundamental axioms of interpretation which serve to shape religious identity. This substitution of "the persuasive" for "the sacramental" is a crucial step in the Weberian process of "disenchantment" which gives rise to modernity.

The Privy Council's first response to Clement vir's bull of excommunication portended a crucial role for Paul's Cross in public disputation over religious identities in the decades immediately following. Committed to a policy of establishing royal headship of the Church, Thomas Cromwell ordered that none should be permitted to preach at Paul's Cross without declaring the authority of the Bishop of Rome (as he was henceforth to be named) as no greater than that of any other foreign bishop. ${ }^{80}$ This was revolution indeed. The long, continuous thread of the late- 
medieval "social imaginary" - the thread which linked the ordered life of temporal religious community through the ecclesiastical hierarchy with the hierarchical order of the entire cosmos, and beyond the realm of the visible, physical reality with the hierarchy of the angels, the communion of the saints, and ultimately to the divine life of the blessed Trinity-had been cut. By defying the bull of excommunication, the core assumption underlying the "moral ontology" of hierarchy had been challenged, and with it the hitherto accepted "horizon" of religious identity. ${ }^{81}$ The anciently presupposed hierarchical "framework" of the "lex divinitatis," ${ }^{82}$ which was understood to link the church and human society through symbol and sacrament to an immanent, created order of being in the cosmos, and beyond the visible realm to the invisible community of the angels and the saints, was effectively abandoned as a "social imaginary." ${ }^{3}$ The severing of the "great chain" (vividly symbolized by Clement viI's excommunication of Henry) might be described as creating a kind of moral-ontological vacuum which — given nature's acknowledged abhorrence of such a condition-was very swiftly occupied by a distinctly different primary axiom, presupposition, framework, moral ontology.

In the process of replacement of the hierarchical assumptions of the old framework, there emerges a remarkable assurance of the possibilities inherent in Persuasion. Whereas the primary point of contact with reality in the "sacramental culture" was through sign and symbol, the contact in the "culture of persuasion" was principally through an appeal to the human faculties of memory, understanding, and will, that is to the identity of the rational human self (imago dei) as interpreted by the Augustinian anthropology of the evangelical reformers. Nowhere is this emergent "culture of persuasion" more vitally evident in the 1530 s than at Paul's Cross. If the authority of the papacy was to be extinguished — and with it the old assumption concerning England's religious identity as derived from and defined by a gradual, sacramentally mediated hierarchy culminating in the jurisdiction of the papacythen this required a radically revised account of the horizon, framework, axiom of religious identity to stand in its place. With this new moral ontology there emerges a new religious identity, and through it a new political identity as well which would bring with it a distinctively modern affirmation of "ordinary life." ${ }^{4}$ The swiftness with which the dissolution of the monasteries was achieved is a measure of the dynamism of this new moral framework and a testimony to the radical decisiveness of the shift achieved by the "first" Reformation of Henry viII. From the 1530s onward, central to the definition of the new framework - this new "moral ontology" - was a deep-seated commitment to a "culture of persuasion." 
From 1534, preachers at Paul's Cross were required to promote a radically new religious assumption, one which cut sharply across the grain of the old. The nature of this new religious identity, moreover, was made evident in both the content and the form or manner of its presentation. As we have seen, the content of the new identity was closely identified with the assertion of the absolute supremacy of the Crown in religious matters, and with it the corollary denial of the jurisdiction of the bishop of Rome - the two were ontologically irreconcilable. The formal presentation of this new identity - i.e. through persuasion - is of equal importance, and arguably, over the longer term, of even greater significance than the actual content of pulpit instruction.

Throughout the revolution of the 1530 s the public pulpit at Paul's Cross not only became one of the principal means of reconstructing the primary assumptions of England's religious identities through promulgation of a revised doctrine; the heavy emphasis upon the formal activity of preaching itself came to exemplify the substance of that new framework. A hermeneutics of public judgment comes to supplant the hermeneutics of sign and symbol, a new "culture of persuasion" displacing the old "sacramental culture." According to the logic of the displaced framework of mediated cosmic hierarchy (whose rejection we claimed at the outset is dramatically symbolized by Henry's rejection of papal jurisdiction), religious identity had been understood hitherto as something given, as intimately identified with the ontological structures and symbolic order of the universe itself. Such an identification of religious and cosmic reality is the essential (and essentialist) claim of what we have been calling "sacramental culture." At the outset of the fourteenth century Boniface viII very succinctly summarized the logic of this culture of sacramental mediation in the bull Unam Sanctam: "it is the law of divinity (lex divinitatis) that the lowest things are led to the highest by intermediaries ... [and] according to the order of the universe, all things are not led back equally and immediately, but the lowest by the intermediary, and the inferior by the superior and ... therefore if the terrestrial power err, it will be judged by the spiritual power." ${ }^{5}$

The new framework of the "culture of persuasion," on the other hand, is built upon the premise that the primary substance of religious identity is not simply given in the hierarchical structure of the cosmos, but is rather to be found in the constitution of the human self as memory, understanding, and will. In this respect, early-modern religious identity, and indeed the modern sense of the "self," is arguably a derived from a formulation of Augustinian anthropology. On this view, religious identity derives properly from inner recognition, conscientious affirmation, and the internal witness of faith and persuasion. The simple fact that in 1534 public authority deems it 
necessary to employ the pulpit to persuade subjects of their primary religious obligation and of the legitimacy of the reconstituted institutions of religious authority-an assumption implicit in Thomas Cromwell's explicit provisions for preaching at Paul's Cross at this time - is itself as important as any specific doctrine being promulgated from the public pulpit. In the context of the public sermons preached at Paul's Cross, therefore, there is a remarkably close correspondence between the rhetorical "form" and the theological "content" in the revolutionary re-definition of religious identity by the Protestant reformers. At Paul's Cross, therefore, the "culture of persuasion" is manifested through both form and content.

Throughout England's radical religious and constitutional transformation of the 1530s, Henry's chief minister Thomas Cromwell simultaneously managed both the intricacies of the legislative programme and a highly sophisticated propaganda campaign through pulpit and press in support of the constitutional agenda before Parliament. ${ }^{86}$ The substance of the pamphlets of the early 1530 s in many respects epitomizes the legislation passed by the Reformation Parliament. ${ }^{87}$ The same is true for the sermons preached at Paul's Cross. What, then, is the significance of Cromwell's resorting to pulpit and press in this concerted fashion to justify a new definition of the church and religious identity? Order is no longer assumed simply as ontologically given but must give an account of itself; there is a revolutionary break with deep, long-held assumptions concerning the nature of the church and its relation to political power, of the relation between religion and the primary social structures, and also of the relation between the conscience of the individual subject and duly constituted political authority. The crucial element in this new relation is especially evident in the perceived need for the encouragement of a public campaign of persuasion. Such a campaign assumes that the moral force of religious identity rests not upon its intrinsic 'given-ness' in the order of religious life, but rather upon active recognition, assent, and embrace by its adherents. The importance of subjective appropriation of the new framework - through persuasion - and the new definition of the communal identity have become intrinsic to the subsistence of that framework. This is the sense of the importance attached to a new "culture of persuasion."

Cromwell's propaganda campaign in pulpit and press sets a radical precedent; it establishes a pattern for the promotion of religious identity in subsequent phases of the English Reformation-or in subsequent English Reformations, if that is the preferred formula-notably in the rapid and comprehensive religious reforms promoted by the Council in the brief reign of Edward vi, in the attempts under Mary to scale back these reforms, and in their re-introduction and eventual 
consolidation after the accession of Elizabeth. Throughout all of these changes, the pulpit at Paul's Cross is consistently at the heart of the action. As we have attempted to show, the relentless effort to promote religious and constitutional reform through a sustained campaign of public persuasion represents the steady undercurrent of the Paul's Cross sermons throughout this period

The perceived need to persuade - that is, to speak to the conscience, to appeal to the perceptions, judgment, discernment, prudence, discrimination, etc. of a discerning religious public - is wholly consistent with the core theological claims of the reformers; such a rhetorical approach is positively required of them. In a very real sense "the medium is the message." 88 To affirm the necessity of addressing the judgment of the discerning, rational individual as the Tudor reformers do is to make a definite claim regarding the means whereby that individual has access to the primary reality. On this view, the moral horizon of the reformers is defined by the medium of persuasion as much as by the message of evangelical or political doctrine. The emergence of the Tudor culture of persuasion in the $1530 \mathrm{os}$ and its flourishing in the "Great Controversy" of the 1560 are evidence of the collapse of the alternative framework of religious identity defined by a semiotic hermeneutic, a moral ontology defined by the concept of hierarchy with its external, sacramental apparatus as the primary means of mediation between temporal and spiritual existence. Indeed the continuing "stand-off" between the reformed Church of England and Catholicism propelled an escalating ideological struggle with an ever-widening gap between religious conscience and institutional authority. As Peter Lake and Michael Questier have concluded with respect to the lessons of the Edmund Campion affair, the emergence of a "rudimentary public sphere" in Elizabethan England was essentially an "ideological" event. "At stake was the line between politics and religion and the definition of what could or should be freely debated in public, of what loyalty and obedience to the magistrate meant." ${ }^{89}$ These issues constitute the crux of what is debated back and forth, week after week, year after year in the pulpit at Paul's Cross. The soteriological formulae of the evangelical avant-garde offer an alternative framework of mediation: salvation by Christ alone (and not by the necessary mediation of the church hierarchical); by grace alone (and not by any natural human powers, faculties, or capabilities); by faith alone (and not by external works or any virtuous activity, e.g. pilgrimages and penances); as revealed in scripture alone (that is, a hermeneutics of scripture as containing a teaching sufficient to salvation without the necessity of additional teaching and traditions of the historical church). The effect of such a hermeneutics is to challenge the chain of hierarchical mediation and to question at its foundation the necessity of 
the church's elaborate sacramental apparatus in the economy of salvation. For the reformers, the unification of souls to the divine is something to be accomplished through the comparative immediacy of the Word spoken and heard, that is through an inner persuasion. This radically re-formed soteriological conception of the relation between the individual soul of the Christian believer and the divine carries with it a corollary of what constitutes the primary social imaginary-ecclesia, the community of individuals who share this relation. Owing to the concept of mediation implied by the "solas" - grace alone, faith alone, etc. - the framework of religious identity and with it the ordering of the relation between the "inner" and "outer," between private and public existence, is transformed almost beyond recognition in a relatively brief span of time. In effect, the increasingly sharp demarcation between the "forum of the conscience" and the "external forum" of institutional life, both religious and civil, necessitates the appearance of a "public sphere" of discussion as the means of mediation between the demands of the two fora-i.e. between conscience and institutional power. This transformation is decisive in the shift from the moral ontology of "sacramental culture" to that of the "culture of persuasion" and, as we have argued, this transformation of moral ontology gives birth in turn to a budding early-modern public sphere.

\section{Notes}

1. The papal breve declared both Henry's divorce of Katherine and his marriage with Anne Boleyn invalid, and pronounced his excommunication from the Church. On the same day Clement also excommunicated Thomas Cranmer, Edward Lee (Archbishop of York), Stephen Gardiner (Bishop of Winchester), and John Longland (Bishop of Lincoln). Although issued on 11 July, it did not come into force until October.

2. Max Weber, "Science as a Vocation," in From Max Weber: Essays in Sociology, trans. and ed. H. H. Gerth and C. Wright Mills (New York: Oxford University Press, 1946), p. 139, 155. See Keith Thomas, Religion and the decline of magic: studies in popular beliefs in sixteenth and seventeenth century England (New York: Oxford University Press, 1997).

3. Peter Marshall and Alec Ryrie, ed., The Beginnings of English Protestantism (Cambridge: Cambridge University Press, 2002); P. Marshall, The Impact of the English Reformation 1500-1640 (London: Arnold, 1997); Diarmaid MacCulloch, "The Myth of the English Reformation," Journal of British Studies 30 (1991), pp. 1-19; Eamon Duffy, The Stripping of the Altars: Traditional Religion in England, 1500-1580 (New Haven and London: Yale University Press, 1992), pp. 11, 377-593. 
4. See Henry Chadwick, "Royal ecclesiastical supremacy," in Brendan Bradshaw and Eamon Duffy, ed., Humanism, Reform and the Reformation: The Career of Bishop John Fisher (Cambridge: Cambridge University Press, 1989), p. 187. C. Haigh, "A Protestant Nation, not a Nation of Protestants," Catholic Herald 25 (1998), p. 7. On the question of the cause of decline in popular late-medieval Catholicism, Haigh observes that "Protestant preaching cannot be the answer ... there was not enough of it about."

5. Ethan Shagan, "Clement Armstrong and the godly commonwealth: radical religion in early Tudor England," Beginnings of English Protestantism, p. 61. Shagan points out that "in England of the early 1530 os ... the hopes of a small evangelical minority lay in the policies of a mercurial king who had begun making dark threats against the pope and the clergy." See p. 78.

6. Lucy E. C. Wooding, Rethinking Catholicism in Reformation England (Oxford: Clarendon Press, 2000), ch. 2 "The Henrician Vision" and ch. 3 "The Henrician Legacy”; Bernard M.G. Reardon, Religious thought in the Reformation (London: Longman, 1995), ch. 10.

7. Fisher and More both suffered execution rather than tolerate the Royal Supremacy, while Gardiner and Bonner both gave the institution their full support. Gardiner published a famous defence of the Supremacy in 1535, defended the institution repeatedly in sermons at Paul's Cross (e.g. in a sermon on 29 June 1548), and republished the treatise De vera obediencia: an oration made in Latine by the ryghte reuerend father in God Stephan B. of VVinchestre, nowe lord Chau[n]cellour of england, with the pteface [sic] of Edmunde Boner ... touchinge true obedience (London: John Day, 1553).

8. 31 Henry viII, c. 14 (1539), Statutes of the Realm, III, pp. 739-42.

9. In this connection, Christopher Haigh accurately identifies three distinct stages of Reformation, or rather three Reformations: the mid to late 1530s, the reign of Edward VI, and the opening years of the reign of Elizabeth. C. Haigh, English reformations: religion, politics, and society under the Tudors (Oxford: Clarendon Press, 1993).

10. Andrew Pettegree, Reformation and the culture of persuasion (Cambridge: Cambridge University Press, 2005).

11. See Mary Polito, Governmental arts in early Tudor England (Aldershot, uk; Burlington, VT: Ashgate, 2005), p. 42. On scaffold performances, see Peter Lake with Michael Questier, The Anti-Christ's Lewd Hat: Protestants, Papists and Players in PostReformation England (New Haven: Yale University Press, 2002), pp. 229 ff.

12. Charles Taylor, Sources of the Self: the making of the modern identity (Cambridge: Cambridge University Press, 1989; repr. 2006), p. 3.

13. In another context Peter Lake and Michael Questier note that “... in Elizabethan England the creation of something like a rudimentary public sphere was not a product of a Puritan opposition to the establishment or state but rather a product of the regime's own efforts to perpetuate and protect itself from a popish threat variously conceived." See their joint article "Puritans, Papists, and the 'Public Sphere' in Early Modern England: The Edmund Campion Affair in Context," The Journal of Modern History 72 (2000), p. 625. 
14. Debora K. Shuger, Habits of thought in the English Renaissance: religion, politics, and the dominant culture (Berkeley: University of California Press, 1990), p. 9.

15. See Richard Rex, “The Crisis of Obedience: God's Word and Henry's Reformation," The Historical Journal 39.4 (1996), pp. 879 ff. "The change in nomenclature from 'pope' to 'bishop of Rome' was a decision taken at the highest level. Throughout 1533 official documents had continued to talk of the 'pope' ... The legislation of 1534 systematically avoids the title "pope."

16. Millar MacLure, The Paul's Cross Sermons, 1534-1642 (Toronto: University of Toronto Press, 1958), pp. 4, 18. For an account of the architecture of the precincts of St. Paul's Cathedral see P. W. M. Blayney, The Bookshops in Paul's Cross Churchyard (London: Bibliographical Society, 1990).

17. Dated 5 March 1560. The Zurich Letters; or, the correspondence of several English bishops and others, with some of the Helvetian reformers, during the reign of Queen Elizabeth, 1558-1579, First Series, ed. H. Robinson (Cambridge: Cambridge University Press for the Parker Society, 1842), p. 71. "You may now sometimes see at Paul's cross, after the service, six thousand persons, old and young, of both sexes, all singing together and praising God. This sadly annoys the Mass priests, and the devil. For they perceive that by these means the sacred discourses sink more deeply into the minds of men, and that their kingdom is weakened and shaken at almost every note." Henry Machyn confirms the great popularity of sermons of Paul's Cross in several entries to his Diary. See Henry Machyn, The Diary of Henry Machyn, Citizen and MerchantTaylor of London, from A.D. 1550 to A.D. 1563, ed. John Gough Nichols (London: Printed for the Camden Society by J. B. Nichols and Son, 1848), the entry for 3 March 1560: "The sam day dyd pryche at Powlles crosse the nuwe byshope of London master Gryndall, in ys rochet and chyminer; and after sermon done the pepull dyd syng; and ther was my lord mayre and the althermen, and ther was grett audyence." See also Machyn's entries for 3 and 16 April and 23 June 1557, 10 and 17 September 1559, 26 November 1559, and 28 February and 15 June 1561.

18. J.R. Maddicot, Simon de Montfort (Cambridge: Cambridge University Press, 1994).

19. MacLure, Paul's Cross Sermons, p. 167.

20. MacLure, Paul's Cross Sermons, p. 4.

21. E. Beresford Chancellor, St. Paul's Cathedral (London and Toronto: J. M. Dent and Sons, 1925). Perhaps a more accurate formulation would employ the plural: "all the English Reformations were accomplished from Paul's Cross. .” See C. Haigh, English Reformations.

22. Jürgen Habermas, The Structural Transformation of the Public Sphere: An Inquiry into a Category of Bourgeois Society, trans. Thomas Burger (Cambridge, Mass.: MIT Press, 1991). See also N. Crossley and J. M. Roberts, ed., After Habermas: new perspectives on the public sphere (Oxford: Blackwell, 2004).

23. Revised and augmented by Jackson Campbell Boswell and Peter Pauls, CrRs Occasional Publications, no. 6. (Ottawa: Dovehouse Editions, 1989). 
24. See Blayney, Bookshops in Paul's Cross Churchyard, which includes modern diagrams of Paul's Cross Churchyard in 1545, 1600, 1640, 1665 \& 1675 (pp. 75-79), and a detailed modern plan of the whole precinct in 1600 (facing p. 3 ).

25. Andrew Pettegree, Reformation and the culture of persuasion (Cambridge: Cambridge University Press, 2005), p. 39.

26. Susan Wabuda, Preaching during the English Reformation (Cambridge: Cambridge University Press, 2002).

27. Letters and Papers, Foreign and Domestic, of the reign of Henry VIII, 1509-1514, ed. J. S. Brewer, James Gairdner, and R.H. Brodie (London: Longman, Green, Longman, Roberts \& Green,, 1862-1932), 7.48 (2).

28. John Foxe, Actes and Monuments (London: Adam and Company, 1873), v. 68. Regarding sermons in general as the single most important vehicle for the advancement of royal policy, see G. R. Elton, Policy and Police: the Enforcement of the Reformation in the Age of Thomas Cromwell (Cambridge: Cambridge University Press, 1972), p. 231.

29. Sir Charles Wriothesley, A Chronicle of England during the reigns of the Tudors, from A.D. 1485 to 1559, ed. W. D. Hamilton, from a transcript made early in the seventeenth century for the third Earl of Southampton (Westminster: Camden Society, 1875-77), vol. 1, pp. 34-35, with reference to a sermon at Paul's Cross by Cuthbert Tunstall, Bishop of Durham.

30. Letters and Papers, Henry VIII, vol. 11, p. 325 .

31. Letters and Papers, Henry VIII, vol. 12(2), p. 258.

32. Wriothesley, vol. 1, pp. 78-79.

33. Gilbert Burnet, The History of the Reformation of the Church of England, ed. Nicholas Pocock (Oxford: Clarendon Press, 1865), vol. 1, p. 475.

34. See note 9 above.

35. R. C. Johnson, John Heywood (New York: Twayne Publishers, 1970), pp. 11-35.

36. Millar MacLure, Register of Sermons preached at Paul's Cross, 1534-1643, revised and augmented by Jackson Campbell Boswell and Peter Pauls, CRRs Occasional Publications, no. 6 (Ottawa: Dovehouse Editions, 1989).

37. Calvin, Institutio christianae religionis (1559), III.10.1 and ff.

38. Wriothesley, vol. 1, p. 175. See Edmund Bonner's Certificatorium factum dominis de privato consilio regio super concrematione quorundam librorum prohibitorum, Guildhall Ms 9531/12, folio $91 \mathrm{v}^{\circ}$; repr. Actes and Monuments (London: Adam and Company, 1873), appendix to vol. v, no. xviii.

39. Letters and Papers, Henry VIII, vol. 21 (2), p. 710

40. William Barlow, A dyaloge describing the originall grou[n]d of these Lutheran faccyons, and many of theyr abusys (London: Wyllyam Rastell, wyth the pryuylege of our souereyn lord kyng Henry [the] viii, 1531).

41. A notable sermo[n] of ye reuerende father Maister Hughe Latemer whiche he preached in ye Shrouds at paules churche in Londo[n], on the xviii daye of Ianuary 1548 (London: John Day and Wylliam Seres, 1548).

42. A notable sermo[n] of ... Latemer, sig. B xi. 
43. Gardiner published learned treatises on both subjects. See An explicatio[n] and assertion of the true Catholique fayth, touchyng the moost blessed sacrament of the aulter with confutacion of a booke written agaynst the same / made by Steuen Byshop of Wynchester; and exhibited by his owne hande for his defence to the Kynges Maiesties commissioners at Lambeth, ([Rouen: R. Caly], 1551) and De vera obedientia ... with the preface of Edmunde Boner ... nowe translated in English and printed by Michael Wood (Roane [Rouen? London: John Day?], 1553).

44. Wriothesley, vol. 2, p. 4; see also Chronicle of the Grey friars of London, ed. John Gough Nichols (London: Camden Society, 1852), p. 56.

45. MacLure's Register includes references to Accession Sermons in 1582, by John Whitgift in 1583, Thomas Cooper, Bishop of Winchester in 1588, Richard Bancroft in 1589, and Fletcher in 1595, and Thomas Holland in 1599. “ ... the seventeenth of Nov [1595], a day of great triumph, for the long and prosperous raigne of her Majestie at London, the pulpit crosse in Paules Churchyard new repaired, painted, and partly inclosed with a wal of bricke: Dr Fletcher Bp of London preached there in prayse of the Queene, and prayer for her Majestie, before the Lord Mayor, Alderman, and Citizens in their best liveries. Which Sermon being ended upon the Church leades the Trumpets sounded, the cornets winded, the Quiristers sung an antheme. On the steeple many lights were burned: the Tower sholt off her ordinance, the Bels were rung, bonefiers made, \&c.” See John Stow, Annales, or, A generall chronicle of England (London: Richard Meighen, 1631), p. 770.

46. Wriothesley, vol. 2, pp. 10, 12

47. Wriothesley, vol. 2, pp. 16-18. Regular "rehearsal" sermons recapitulated sermons previously preached at Paul's Cross. See "A sermon concernynge the tyme of Rebellion," in Torrance Kirby, The Zurich Connection and Tudor Political Theology (Leiden and Boston: E. J. Brill, 2007), pp. 149-79. For a description of the 1549 rebellions, see Anthony Fletcher and Diarmaid MacCulloch, Tudor Rebellions (Harlow: Longmans, 2004) and esp.pp. 52-64 on the Western Rebellion.

48. A fruitfull sermon made in Poules churche at London in the Shroudes the seconde daye of Februari (London: John Day, 1550).

49. For his formal definition of the "public sphere" see Jurgen Habermas, p. 27.

50. Certe $[n]$ godly, learned, and comfortable conferences, betwene the two reuerende fathers, and holye martyrs of Christe, D. Nicolas Rydley late Bysshoppe of London, and M. Hughe Latymer sometyme Bysshoppe of Worcester, during the tyme of their emprysonmentes. Whereunto is added. A treatise agaynst the errour of transubstantiation, made by the sayd reuerende father D. Nicolas Rydley (Strasbourg: Rihel, 1556).

51. See Machyn, p. 41; Wriothesley, vol. 2, pp. 99-100; Grey Friars Chronicle, p. 83.

52. Machyn, p. 69, referring to 30 September 1554.

53. Machyn, p. 78: "The ij day of Desember dyd com to Powlles all prestes and clarkes with ther copes and crosses, and all the craftes in ther leverey, and my lorde mayre and the althermen, agaynst my lord cardenall('s) commyng; and at the bysshopes of London plase my lord chansseler and alle the bysshopes tarehyng for my lord card- 
enall commyng, that was at ix of the cloke, for he landyd at Beynard Castell; and ther my lord mayre reseyvyd hym, and browgth ym to the Powllse, and so my lord chanseler and my lord cardenall and all the byshopes whent up in-to the quer with ther meyturs; and at $x$ of the cloke the Kyng('s) grace cam to Powlles to her mase with iiij C. of gaard, on C. Englys, on C. HeAlmen, on C. Spaneards, on C. of Swechenars, and mony lords and knyghtes, and hard masse. Boyth the quen('s) chapell and the kynges and Powlles qwer song."

54. On 20 November 1558. Machyn, p. 69

55. Zurich Letters, 1.4.

56. Machyn, p. 219. "The xxvj day of November dyd pryche at Pow [1's Cross] master Juell, byshope of Salysbere, and ther was my lord mare and the althermen and mony of the courte, and ther was grett audyense as (has ever) bene at Powlles Crosse." For two excellent scholarly accounts of Jewel's Challenge Sermon, see Gary Jenkins, John Jewel and the English National Church: the dilemmas of an Erastian reformer (Aldershot, UK: Ashgate, 2006) and John Booty, John Jewel as apologist of the Church of England (London: Published for the Church Historical Society [by] SPCK, 1963).

57. Machyn, p. 228

58. Jenkins, p. 71.

59. The true copies of the letters betwene the reuerend father in God Iohn Bisshop of Sarum and D. Cole: vpon occasion of a sermon that the said Bishop preached before the Quenes Maiestie, and hir most honorable Counsel. 156o. Set forthe and allowed, according to the order appointed in the Quenes Maiesties iniunctions. Cum gratia \& priuilegio Regice Maiestatis per septennium [London: John Day, 1560?].

6o. John Jewel, Apologia ecclesice anglicance (Londini: [Apud Reginaldum vvolfium], 1562).

61. An apologie or answere in defence of the Churche of Englande (London: Reginald Wolfe, 1564). For a modern edition of the Apologie, see Valerie Wayne, ed., Anne Cooke Bacon (Aldershot, UK: Ashgate, 2000). See Lynne Magnusson's entry on Anne Cooke, Lady Bacon in ODNB (2004).

62. An ansvvere to Maister Iuelles chalenge, by Dr Harding (Louvaine: Iohn Bogard, 1564).

63. A proufe of certeyne articles in religion, denied by M. Iuell: sett furth in defence of the Catholyke beleef therein, by Thomas Dorman (Antwerp: Iohn Latius, with priuilege, 1564).

64. A disproufe of $M$. Novvelles reproufe (Antwerp: Iohn Latius, 1565) and A request to $M r$. Jewel that he keep his promise made by solemn protestation in his late sermon at Paul's Cross (1567; repr. [Menston]: Scolar Press, 1973).

65. Thomas Harding, A confutation of a booke intituled An apologie of the Church of England (Antwerpe: Ihon Laet, 1565).

66. Thomas Stapleton, A fortresse of the faith: first planted amonge vs englishmen, and continued hitherto in the vniuersall Church of Christ. The faith of which time protestants call, papistry (Antwerpe: Ihon Laet, 1565).

67. Booty, ch. 1; Jenkins, pp. $70 \mathrm{ff}$. 
68. A retur [ne of vn]truthes vpon [M. Jewel]les replie: Partly of such, as he hath slaunderously charg[ ... ] Harding withal (Antwerpe: Iohn Latius, at the signe of the Sower, 1566). Jewel, A defence of the Apologie of the Churche of Englande: conteininge an answeare to a certaine booke lately set foorthe by $M$. Hardinge, and entituled, A confutation of \& $c$ (London: Henry Wykes, 1567).

69. H. Osorius, An epistle of the Reuerend Father in God Hieronimus Osorius Bishop of Arcoburge in Portugale, to the most excellent Princesse Elizabeth by the grace of God Quene of England, Fraunce, and Ireland. \& c. Translated oute of Latten in to Englishe by Richard Shacklock M. of Arte and student of the ciuill lavves in Louaine (Antwerp: By Iohn Latius, 1565).

70. Walter Haddon, Contra Hieron: Osorium, eiusq[ue] odiosas insectationes pro Euangelicae veritatis necessaria Defensione, Responsio Apologetica (London: T. Day, 1577). See Lawrence V. Ryan, “The Haddon-Osorio Controversy (1563-1583)," Church History 22.2 (1953), pp. 142-54.

71. While the exchange between Jewel and Harding was the principal action, other significant contributions were made by Nicholas Sanders, The Supper of our Lord set forth according to the truth of the Gospell and Catholike faith (Louvain, 1566); John Martiall, A replie to $M$. Calfhills blasphemous answer made against the Treatise of the crosse (Louvain: John Bogard, 1566); Richard Shacklock, translator of A most excellent treatise of the begynnyng of heresyes in oure tyme, compyled by the Reuerend Father in God Stanislaus Hosius Byshop of Wormes in Prussia (Antwerp: Diest, 1565); Thomas Heskyns, The parliament of Chryste: auouching and declaring the enacted and receaued trueth of the presence of his bodie and bloode in the blessed Sacrament, and of other articles concerning the same, impugned in a wicked sermon by M. Iuell (Antwerp: Wm. Silvius, 1565); Robert Poyntz, Testimonies for the real presence of Christes body and blood in the blessed Sacrame [n] tof the aultar (Louvain: John Fowler, 1566); and William Allen, A defense and declaration of the Catholike Churchies doctrine, touching purgatory, and prayers for the soules departed (Antwerp: I. Latius, 1565).

72. See W. Haugaard, "Renaissance Patristic Scholarship and Theology in Sixteenthcentury England," Sixteenth Century Journal 10.3 (1979), pp.37-6o, see p. 43.

73. The reference is to Marshall McLuhan's thesis that the printing press changed civilization by creating a "new human environment." Understanding Media: the Extensions of Man (New York, 1950), p. vi, quoted by Haugaard, p. 38. What applies to the press applies a fortiori to the public pulpit.

74. Taylor, Sources of the Self, pp. 5-8, 9, 10, 41, passim.

75. Taylor, Sources of the Self, p. 7

76. Taylor, Sources of the Self, p. 28

77. Taylor, Sources of the Self, p. 26

78. Taylor, Sources of the Self, p. 26

79. Nicholas Sanders, A treatise of the images of Christ: and his saints: and that it is vnlaufull to breake them, and lauful to honour them. With a confutation of such false doctrines as 
M. Iewel hath vttered in his Replie, concerning that matter (Louvain: apud Ioannem Foulerum, 1567), Sig. ij v. Quoted by Booty, p. 41.

80. See Richard Rex, “The Crisis of Obedience: God's Word and Henry's Reformation,” The Historical Journal 39.4 (1996), pp. 879 ff. “The change in nomenclature from 'pope' to 'bishop of Rome' was a decision taken at the highest level. Throughout 1533 official documents had continued to talk of the 'pope' ... The legislation of 1534 systematically avoids the title 'pope'."

81. Taylor, Sources of the Self, pp. 5-8, 9, 10, 41, passim.

82. Famously formulated two centuries earlier in the Bull "Unam Sanctam," Pope Boniface viII defends the doctrine of the papal supremacy (plenitudo potestatis), and therefore the necessary subordination of temporal to spiritual jurisdiction, by invoking the concept of lex divinitatis (law of divinity), the law of the so-called "great chain" set forth by the sixth-century Syrian Neoplatonist Pseudo-Dionysius the Areopagite: "For according to the Blessed Dionysius, it is the law of divinity (lex divinitatis) that the lowest things are led to the highest by intermediaries. Then, according to the order of the universe, all things are not led back equally and immediately, but the lowest by the intermediary, and the inferior by the superior ... Therefore if the terrestrial power err, it will be judged by the spiritual power."

83. Charles Taylor, Modern Social Imaginaries (Durham, London: Duke University Press, 2004).

84. Taylor, Sources of the Self, p. 13

85. Unam Sanctam, "Extravagantes Communes," Corpus Iuris Canonici, ed. Emil Friedberg (Leipzig: B. Tauchnitz, 1879; reprinted Graz: Akademische Druk-u. Verlagsanstalt, 1955; 1959), vol. 2, col. 1245-46.

86. G. R. Elton, Reform and Reformation: England 1509-1558 (Cambridge, Mass.: Harvard University Press, 1977), p. 157: "Cromwell obtained a grip on the press in latter part of 1533. Under his patronage a very different body of writers and writings took over the task of discussing the issues of the day; production turned from controversy to constructive thought."

87. According to Franklin Le Van Baumer, Henry viII and Cromwell devoted almost as much attention to the printing press as to the parliamentary session. See The Early Tudor Theory of Kingship (New York: Russell and Russell, 1966), pp. 35-84. See p. 39: "Henry virI exercised a dictatorship of the press which, judged by its results, was just about as effective as any western Europe has ever seen. The opposition, denied the use of the English printing press, was either driven abroad to publish, or else forced to circulate its views in manuscript."

88. On this link of medium and message, see Haugaard, pp. 37-43.

89. Peter Lake and Michael Questier, "Puritans, Papists, and the 'Public Sphere'," Journal of Modern History 72 (2000), p. 625. 